\title{
Determinants of Board Size and Its Composition: Evidence from Nigerian Manufacturing Sector
}

\author{
Mustapha Y. I. ${ }^{1}$, Nafiu A. I. ${ }^{2}$, Abdul F. A. ${ }^{3}$ and Omolekan, O. J. ${ }^{4}$ \\ ${ }^{1}$ University of Ilorin, Ilorin, Nigeria. \\ ${ }^{2}$ Federal Polytechnic Offa, Nigeria \\ ${ }^{3,4}$ Department of Business Administration, Faculty of Management Sciences, University of \\ Ilorin, Ilorin, Nigeria \\ 1'ismyoriss@gmail.com, ${ }^{2}$ nafiu123@yahoo.com, ${ }^{3}$ falilatabdul@gmail.com, \\ ${ }^{4}$ o.omolekan@gmail.com
}

\begin{abstract}
This paper examines the determinants of corporate board size and its composition in Nigeria using listed manufacturing firms as study area. The objective of the paper is to determine the effect of firms' characteristic on board size. The study collected secondary information from thirty listed manufacturing firms that met the requirement for selection as sample between 2006 and 2018 through Nigerian Stock Exchange's Fact Books. Multiple regression analysis was used as analytical technique. Using panel data OLS pooled method of estimation, the paper found that firm size, profitability, and growth opportunities are strong determinants of board size. Similarly, the results indicated that CEO-duality and profitability were determinants of board composition in the study. It is recommended that appointment into corporate board should be based on proven demonstration of high level of expertise, merit and due consideration to firms' characteristics instead of mundane factors that would not enhance shareholders' wealth.
\end{abstract}

Keywords: Board Size, Board Composition, CEO-duality, Firm Characteristics, Corporate Governance

Copyright: (C) 2020 Mustapha Y. I., Nafiu A. I., Abdul F. A. and Omolekan, O. J. This is an open access article distributed under the Creative Commons Attribution License, which permits unrestricted use, distribution, and reproduction in any medium, provided the original work is properly cited.

Correspondence: ismyoriss@gmail.com

ORCID of authors: Mustapha Y. I. - https://orcid.org/0000-0002-6303-0536

Nafiu A. I. - https://orcid.org/0000-0002-7357-5927

DOI: http://doi.org/10.4038/kjm.v9i1.7623 


\section{Introduction}

The determination of appropriate corporate board size and its composition is critical to organizational success especially in making viable decisions. Globally, organizational stakeholders are now interested in having appropriate, efficient and functional corporate boards to drive their strategic goals (Ifeanyi, Olagunju \& Adeyanju, 2011). In fact, the size and composition of corporate boards have become critical issues in corporate governance environment all over the world because of the role corporate board members are expected to perform in the management of business organizations. According to Steier (1998) board structure supposes to be set in a way that it supports the unique nature of the industry. In the context of the manufacturing industry, Conger, Finegold and Lawler (1999) provide guidelines on desirable board composition, members' representation and the size of corporate boards. They suggest that corporate boards should be composed of a mixture of members with different skills that are related to expertise in corporate management. Boards are also required to be structured in a way that they can accomplish their main roles of attracting and mobilizing resources as well as assisting in identifying the organizational core mission (Campion \& Frankiewicz, 1999). These roles can be integrated into two major roles of corporate boards: monitoring and advising Chief Executive Officers (CEOs) on various matters (Chambers, Harvey, Mannion, Bond \& Marshall, 2013; Hillman \& Dalziel, 2003). The roles in the views of Hillman and Dalziel (2003) are grounded on agency and resource dependency theories. The theories suggest that the ability of the board to effectively play its roles depend largely on how the board is structured and composed (Boone, 2007).
In the light of the enormous tasks and responsibilities of the board, its structure deserves equal attention and hence the Nigerian Stock Exchange Code of corporate governance (SEC Code) stipulates that members of the board should not be less than five (5), stressing that the board should be of sufficient size relative to the scale and complexity of the company's operations and that the board should be made up of the Chairman, the Chief Executive Officer (CEO), the Executive Directors, the Non-executive Directors, and Independent Directors (SEC Code sections 5.1 - 5.5, 2011). From the above highlights, it is clear that the NSE code of corporate governance attaches great importance to the structure of corporate boards. Consequently, critical insights into the underlying dynamics of board size and its composition are as important as the track records and background of board members. However, in most developing economies such as Nigeria, appointments into corporate boards were largely influenced by political consideration and government interventions, social and family connections (Ifeanyi, Olagunju \& Adeyanju, 2011). This practice did not give way to corporate ethics to facilitate corporate board members to be appointed or constituted on a merit basis despite the movement of the economic system from a controlled regime to a liberalized environment. Hence, this study examines the determinants of corporate board size and its composition with a particular focus on corporate boards and the firm's characteristics.

Board size and its composition are important to board structure variables because the findings of the extant researches such as Pearce and Zahra (1992), Johnson, Daily and Ellstrand (1996), Raheja (2005), Markarian and Parbonetti (2007), Linck, Netter and Yang, (2008), Coles, Daniel and Naveen (2008), Palenzuela and Merino (2009), 
Ifeanyi, Olagunju and Adeyanju (2011), Chen (2011) and Mallin, Farag, and OwYong (2014) indicated that board structures affect boards' effectiveness. For instance, agency theory believes that small boards operate more effectively than large boards because of lower coordination costs and less free-rider problems (Chambers, Harvey, Mannion, Bond \& Marshall, 2013; Jensen \& Meckling, 1976; Yermack, 1996).

Similarly, resource dependence scholars suggest that board size affects an organization's ability to form environmental links to secure critical resources. Board composition (board independence) is also an important board structure variable that determines how independent from management the corporate board of a firm is? Empirical studies such as the work of Chambers, Harvey, Mannion, Bond \& Marshall (2013) and Raheja (2005) examined monitoring and advising roles of the board, and discovered that outsider dominated boards are of greater value in organizations because of their ability to monitor and control management (Johnson, Daily \& Ellstrand, 1996) through a variety of resources that could be brought by outsiders (Chen, 2011). This finding was further corroborated by the study of Andres and Vallelado (2008) which discovered that bank board composition and size are related to directors' ability to monitor and advise management and that larger and not excessively independent boards might prove more efficient in monitoring and advising functions.

The review of the available empirical studies on the determinants of board size and its composition revealed that scholars from the advanced economies extractions such as those from Europe, America and Asian have made efforts to demonstrate the relationship that exists between the variables without conclusive results. However, the findings of these studies cannot be wholly applicable to developing economy like Nigeria owning to peculiarity, hence, there seems to be visible gaps. Added to this, is the paucity of research conducted in this area in Nigeria has provided limited information about determinants of board size and composition, and this therefore offers the current study the opportunity to bridge these research gaps. Also, several countries including Nigeria have issued recommendations and guidelines for best governance practices especially on the board size and its composition (SEC Code, 2003 and 2011; Cadbury, 1992). The expectation is that adherence to these guidelines by boards will improve firm performance. However, whether better performance is recorded by firms that follow the best practice recommendations regarding board structures remains a question to be examined in the Nigerian context empirically.

It has been argued by some authors that the effectiveness of a board depends on the optimal mix of outside and inside directors. Thus, board size and its composition were posited to affect the value of an organization and the boards of directors are expected to oversee and advise the organization's manager (Hillman \& Daniel, 2003). There is need for board members to have a structure that supports such activities to efficiently perform these functions (Mallin, Farag \& Ow-Yong 2014; Chambers, Harvey, Mannion, Bond \& Marshall, 2013; Jackling \& Johl, 2009). The fact that the firms used as the sample for this study came from Nigerian manufacturing firms allows examining the determinants of board size and composition in Nigerian firms. Evidence of the determinants of board size and its composition will assists firms in making appropriate choices regarding board appointments for creating and improving firm value. Hence, the identification of this gap motivates the conduct of the current study. 
The above review highlights that board size and its composition (level of independence) can affect board effectiveness and that the boards of directors perform both the advisory and monitoring functions. Therefore, for members to perform these functions efficiently, corporate firms need to have structures that support such activities. This study is therefore designed to empirically examine the determinants of board size and its composition in the Nigerian manufacturing sector. Specific objectives of the study are to:

i. analyze the effect of firm characteristics on board size; and

ii. determine the relationship between firm characteristics and board composition.

\section{Literature Review Hypotheses Development}

and

\section{Board size and board composition}

Issues concerning board independence (such as independence of board committees), diversity (e.g functional backgrounds, firm and industry experience, etc) of board members, and CEO duality normally constitute what it refers to as board composition. It also refers to the combination of executive directors or inside directors (including the chief executive officers, who in most cases are senior managers and employees of the company with a proper contract of service with the company) and nonexecutive directors (NEDs) in the board (Liao, Luo \& Tang, 2015). Non-executive (independent outside) directors are often appointed from outside the organization to monitor the executive management and these non-executive directors may have no material interest in the organization. They are appointed due to huge qualifications, expertise and experience and they may effectively influence the board's decision and ultimately add value to the firm
(Fields and Keys, 2003). Non-executive directors are not expected to participate in the day to day management of the company. Generally, when the number of outside directors greater, there will be a greater level of board independence and the board composition will be better. In addition, the Security and Exchange Commission (SEC) code requires every public company to appoint at least one independent NEDs. It provides that such a NED should have no contractual relationship with the company, should act independently and should be a key member of the board to ensure that minority interests are adequately protected (SEC, 2011).

Corporate board size, on the other hand, refers to the total number of board members that sit on the board of a company. It comprises of the Chairman, the CEO, the executive and non-executive directors and all other directors by whatever name they may be referred to. Corporate board size has financial costs implications, that is, 'ceteris paribus' larger boards consume more pecuniary and nonpecuniary firm resources in the form of remuneration and perquisites than smaller boards. This is one of the reasons why some firms keep the size of their board minimal (Jackling \& Johl, 2009). SEC code on corporate governance provides that all public companies must have a minimum of five directors. It did not set maximum board size. The SEC codes also did not specify the exact number of directors that should form a board. However, it sets out a general principle that the board should be of sufficient size relative to the scale and complexity of the company's operations (SEC code 2011). This suggests that even though the code admits that a company's board size may probably affect its performance.

CEO duality implies a situation where the same person occupies the position of the chairman of the board, as well as the CEO of the firm. Several other studies (Weir \& 
Laing, 2001; Boyd, 1995; Muth \& Donaldson, 1998) affirmed that the power of the CEO is measured using a dummy variable, which takes a value of 1 if the CEO and chairman are the same person and 0 otherwise. Here, it is expected that CEO performs a dual function as the chairman of the board and at the same time function as the chief executive of the firm. It is expected that this will reduce the agency problem existed in the organization as the goal and objectives of the board can easily be aligned with the firm with minimal conflict. The decision is faster and involving while performance can be enhanced. Though, some authors (Hsiao, 2003; Guest, 2008; and Iwasaki, 2008) disapprove CEO duality as it encourages some sharp practices and unnecessarily undue influence some decisions.

\section{Theoretical Background}

Two theories that are relevant for the determination of board size and its composition are discussed in this section. These are the agency and resource dependence theories. These are discussed below.

\section{Agency Theory}

Agency theory describes the relationship between two parties with conflicting interests: the agent and the principal (Jensen \& Meckling, 1976). Agency theory focused on the alignment of the interests of managers and owners. The theory is based on the assumption that there is the conflict between the interests of managers and those of shareholders represented by directors (Fama \& Jensen, 1983; Fama, 1980; Jensen \& Meckling, 1976). The theory underlies the importance of monitoring and governance functions of boards (Pearce \& Zahra, 1992; Zahra \& Pearce, 1989) and the need for the establishment of mechanisms to protect shareholders from the inherent conflict between the interests of the firm's owners and its managers. The theory suggests that boards should consist of outside and independent directors and that the position of Chairman and CEO should be separate (Daily \& Dalton, 1994). The proponents of the theory maintain that the advisory and monitoring roles are constrained mainly when the Chairman is under the influence of the CEO, hence the agency cost becomes greater and the firm value will be negatively affected (Daily, Dalton, Johnson, \& Ellstrand, 1999).

\section{Resource Dependence Theory}

The central thrust of the resource dependence theory according to Pfeffer and Salancik (1978) is the exertion of control over the environment to co-opt the resources needed for firms to survive. Cooptation as a concept has implications on the important roles played by the board, as well as its structure. The theory maintained that boards can be used as a mechanism to form links with the external environment for critically needed resources. Inter-organisational linkages (e.g. appointment of outside directors and board interlocks), can be adopted for managing environmental contingencies. Directors who are prestigious in both their communities and professions can be of help in sourcing required timely information for executives. Pfeffer and Salancik (1978) asserted that, when an individual is appointed to a board by an organisation, the individual is expected to support the organisation, concern himself with its problems, favourably present it to others and try to aid it to raise organizational performance and increase returns to shareholders. He further pointed out that the board's co-optation role, which includes establishing contacts and raising funds, best explains board composition.

\section{Development of research hypotheses}

In line with the earlier stated objectives of the study and in congruence with the conceptual issues, literature and theories 
propounded. This study formulated four hypotheses. The hypotheses are formulated from past empirical studies:

Previous empirical studies have used agency theory to develop hypotheses concerning the economic determinants of board size and composition (Beatty \& Zajac, 1994). It has been argued that the board optimal size and composition is a function of the board of directors and firm characteristics (Raheja, 2005). Existing literature reveals that one of the most vital explanatory variables for board composition is firm size. Larger firms need directors to provide wider expertise and, hence, require more outsiders on the board (Denis \& Sarin, 1999; Booth, Cornett \& Tehranian, 2002; Lehn, Patro \& Zhao, 2009; Linck, Netter \& Yang, 2008). Moreover, because their large size creates more crucial agency problems, larger companies demand more outsider directors (Boone, Field, Karpoff and Raheja, 2007). Pincus, Rusbarsky and Wong (1989), contend that larger firms tend to have larger boards and more outsiders on their boards. Theoretical propositions suggest that a bigger firm would tend to have a larger board of directors as these firms are more complex and require more diverse expertise on board. Based on the argument of the advisory need, it was emphasized by Klein (1998) that the extent to which a firm depends on its environment for resources increases the need for good advice. The aforementioned works of the literature suggested an evaluation of firm size on board size and independent outside directors. With this, the study hypothesize:

$\mathrm{HO}_{1}$ : Larger and complex firms have larger boards and a greater proportion of outside directors.

In Hermalin and Weisbach's (1998) model, the case is stated that board composition varies with the bargaining ability of the CEO. Where one person is both the Chief Executive Officer (CEO) and the Chairman of the board, it is found that the proportion of executives is generally smaller. Kieschnick and Moussawi (2004) argued that board independence shrinks with managers' influence (CEO power). This implies that the fraction of outsiders on the board will be negatively related to the CEO's power. This variable has yielded inconclusive results. Bathala and Rao (1995), for instance, show a negative relationship between CEO power, measured by CEO tenure, and the proportion of nonexecutive directors on a board, thus confirming the idea that powerful CEO may prefer less independent board. However, Whidbee (1997) studied the banking industry in the USA and concluded that there is no relationship between CEO tenure and the proportion of non-executive directors on a board. Given the mixed evidences from previous studies, it is important to examine the effect of CEO-duality on board size and board composition. Thus, the study hypothesize:

$\mathrm{HO}_{2}$ : Firms characterized with strong CEO power have smaller boards and smaller proportion of outside directors.

Another variable that has been identified as affecting board composition is investment or growth opportunities available to a firm. This has also produced mixed results. Literature has shown that there is an inverse relationship between the proportion of outside directors on a board and a firm's investment or growth opportunity. Bathala and Rao (1995) also affirmed this position. On the contrary, however, Whidbee (1997) finds no evidence of a relationship between a firm's growth or investment opportunity and the proportion of non-executive directors. Masulis, Wang and Xie (2012) assert that larger firms with greater growth opportunities and a higher total sale are more likely to induce more board members. Conversely, monitoring is said 
to be more difficult in high growth firms due to greater information asymmetry between insiders and outsiders. This increases the monitoring costs. Therefore, monitoring costs are usually related to firm growth and have a negative impact on the size of the board and independence (Boone, Field, Karpoff, \&Raheja, 2007; Guest, 2008; Linck, Netter \& Yang, 2008) and outsider directors proportion (Kim, Kitsabunnarat \& Nofsinger, 2007; Guest, 2008). In view of the mixed empirical evidences, it was revealed that firms with higher growth increase the monitoring costs, which will result in smaller and less independent boards and there is need to be evaluated this. Based on the foregoing, the study hypothesize:

$\mathrm{HO}_{3}$ : Firms characterized by high growth opportunities and profitability have smaller boards and smaller proportion of outside directors.

Firm complexity, proxied by age has been linked to many decisions of the firm. For example, Berger and Udell (1998) and Gregory, Rutherford, Oswald and Gardiner (2005) demonstrated that firms go through the financial growth cycle and their capital structures vary with the age. A study conducted by Boone et al. (2007) revealed that as firms grow, boards also grow in response to the increasing needs and benefits associated with monitoring and specialisation by board members. For example, younger firms are expected to have smaller earnings than older ones because they have less experience in the market, are still building their market position, and normally have a higher costs structure (Lipczinsky\& Wilson, 2001) while older organizations may be getting to the end of their product life cycle. Boone, Field, Karpoff and Raheja (2007) also suggest that firm age results to increases in complexity leading to the need to source for outside directors and larger board. Relying on the available mixed empirical evidences, it is expedient to examine the influence of board size and its composition increase with age.

Many earlier studies, including those of Kaplan and Minton (1994) and Linck, Netter and Yang, (2008), have acknowledged that the higher the debt ratio of a company, the stronger the managerial monitoring function of its corporate board. This is because persistent monitoring pressure on a company from outsider owners afraid of bankruptcy and creditors trying to recover their credit has a strong effect on board structure. Nonperforming accounts payable and bank loans are still of serious economic concern all over the world. A higher debt ratio implies a greater need for advice due to the greater dependence on external resources (Pfeffer, 1972; Klein, 1998). Booth and Deli (1999) demonstrate that bankers often hold board positions to provide expert advice on capital markets. Rather than to replace current board members, these outside experts seem to be added to the existing board. This notion is endorsed by Coles, Daniel and Naveen (2008), who say that more leverage leads to a bigger board. With this, it is important to assess the impact leverage has on outside and inside directors composition. However, the study hypothesize:

$\mathrm{HO}_{4}$ : Firms characterized by high leverage and complexity has larger boards and a higher proportion of outside directors.

\section{Methodology}

\section{Population, Sample Size and Sampling Technique}

The total population of this study encompasses 57 quoted manufacturing firms operating in different sectors of the Nigerian Stock Exchange (NSE). The criteria for the selection of the sampled firms are based on the availability of data and their year of incorporation. Hence, among the 57 listed manufacturing firms in the Nigerian Stock Exchange, this study 
selected 30 manufacturing firms that possess the required data as at year 2018 . The justification for this is that the period under study fell within the period before the code of corporate governance provisions for listed firms in Nigeria was reviewed. Furthermore, in determining what constitutes the manufacturing firms used, the study relied on the information published on the Nigerian Stock Exchange Fact (NSE, Fact Book, 2019). Consequently, the sampling technique adopted in this study was purposeful sampling. The choice of listed firms was based on the fact that the Nigerian Stock Exchange is statutorily saddled with the responsibility of collecting, collating and publishing annually the financial records of all the coated firms. Also, Daniel (2005) expatiates further that the Nigeria Stock Exchange (NSE) ensures that records of listed firms are readily available and organized to meets the corporate governance standard.

\section{Data and Source}

The data used in this study comprises annual data covering thirteen years i.e. from 2006 to 2018 for thirty (30) listed manufacturing firms on the Nigerian Stock Exchange. Performance-related data of the firms were elicited from the Fact Books of the Nigerian Stock Exchange, while, board variables related data were sourced from the annual reports and websites of the selected firms.

\section{Dependent Variables}

The dependent variables are board composition and board size (i.e. board independence). Board size (bds) is measured in this study by the total number of board members as adopted by many previous authors (Hermalin \& Weisbach, 1998; Yermach, 1996; Bhagat \& Black, 2002; Adam \& Mehran, 2003; Bonne et al, 2007; Coles et al., 2008). Board composition (bdc) is the ratio of nonexecutive board members to the size of the board. John and Senbet (1998) asserted that where there are more non-executive members than executive members on board, such board is deemed independent.

\section{Independent Variables}

The total asset of a firm is often treated as a proxy for measuring firm size (fz) and the need for a higher amount of advice to the board (Booth \& Deli, 1996; Fama \& Jensen, 1983). As firms grow in size, they become a lot more complex to manage. Following Kyereboah-Coleman (2007), this study has used total assets as a proxy for measuring firm size because required data on total assets were readily available and obtainable from the data sources of the firms that constitute the sample used in this study. The annual rate of change in turnover is used as a measure of Firm growth opportunities (gro). This is given by Kyereboah-Coleman (2007) as:

\section{(TurnOvert-TurnOvert-1) TurnOvert-1}

CEO duality implies a situation where the same person occupies the position of the chairman of the board, as well as the CEO of the firm. Several other studies (Weir \& Laing, 2001; Boyd, 1995; Muth \& Donaldson, 1998) affirmed that the power of the CEO is measured using a dummy variable, which takes a value of 1 if the CEO and chairman are the same person and 0 otherwise.

A study conducted by Boone et. al. (2007) relates profitability to board structure. Profitability was measured as Return on Asset (ROA) and was calculated as the ratio of Earnings Before Interest and Taxes (EBIT) to Total Assets (TA). This was adopted as our measure of profitability (PRO). Leverage (lev) which is measured by Iwasaki (2008) as the ratio of total debt (TD) to total assets (TA) is used for testing the impact of leverage on board composition. 
Age (age) is used as a proxy for firm complexity (this is measured by the firms' number of years of operation, starting from the year of incorporation).

\section{Model Specification}

In carrying out this study, panel data multiple regression technique was used. Klevmarken (1989) and Hsiao (2003) revealed that the use of panel data gives more advantages over the conventional time-series approach. Thus, the study employs a modified version of the econometric model of Miyajima, Omi and Saito (2003) which is given as:

yit $=b 0+$ b1 git + eit..............

Where $i=1 \ldots \ldots \ldots \ldots, n ; t=1 \ldots \ldots \ldots . . t$, with i denoting our cross-sectional dimension firms, and $t$ representing the time-series dimension. b0 is a scalar. yit stands for dependent variables board composition (bdc) and board size (bds) for firm $i$ in time $t$. git is a vector of firm characteristics independent variables; profitability (pro), firm size (fz), firm age (age), growth opportunities (gro), leverage (lev), and a dummy variable 1 , for (ceo) to capture if the board chairman is the same as the ceo and 0 otherwise, while eit, is the error term.

From the above discussion, we specify equation 2 and 3 as follows:

bds $=f($ firm characteristics $) \ldots \ldots \ldots \ldots \ldots . .2$

$\mathrm{bdc}=f($ firm characteristics $) \ldots \ldots \ldots \ldots \ldots 3$

Equation 2 and 3 represents the composite equation for the dependent variables board size and board composition respectively.

The firm characteristics which constitute the independent variables in the equation are:

Firm profitability (pro), firm size(fz), firm growth opportunity (gro), Ceo duality (ceo), firm age (age), and leverage (lev).
The expanded form of equation 2 and 3 are specified as:

yit, = bdsit = b0 + b1 proit + b2fzit + b3groit + b4ceoit + b5ageit + b6levit + eit... 4

yit, = bdcit $=$ b0+ b1 proit + b2fzit + b3groit + b4ceoit + b5ageit + b6levit + eit......5

We specify the individual fixed effects equation which captures the individual characteristics that are specific with each firm but do not change over time as:

yit,=bdsit $=$ bi + b1 proit + b2fzit + b3groit + b4ceoit + b5ageit + b6levit + eit.......8

yit,=bdcit $=$ bi + b1proit + b2fzit + b3groit + b4ceoit + b5ageit + b6levit + eit......9

where bi is fixed effect parameter that can be estimated directly.

The apriori expectation of the signs of the parameter estimates are:

For board size (bds), b1, b2, b5, b6>0, while b3, b4<0.

For board composition (bdc), b2, b5, b6 $>0$, while b1, b3, b4 <0

To minimize the multi-colinearity problem, we run regressions with few variables at a time (Strom, Espallier and Mersland, 2010). The application of panel data estimation which gives more data points helped to reduced even further Multi-collinearity problem (Wooldridge, 2006).

\section{Presentation of Results and Discussions} Descriptive Statistics of Board size and
Board Composition 
Table 1 (Appendix A) presents the descriptive statistics of the variables of interest. It indicates that majority of the firms have been operating in the Nigerian economy for more than 43yearsand the board size of these firms ranges between a minimum of 3 and maximum of 14 members with the majority of them having 7 board members.

SEC code on corporate governance provides that all public companies must have a minimum number of five (5) board of directors but did not set a maximum number (SEC code, 2003). Therefore, compared to an average of eleven in the developed country such as U.S. (Prasanna, 2012) and Ghana (Kyereboah-Coleman, 2007), this result could be considered a small board size. Thus, the study observed fluctuation in the number of directors less than the minimum number recommended by the security exchange code in 2003 during the sampled period due to some macro-economic variables outside the scope of this study. This lapses might have contributed to the overall decline performance in the sector.

The 0.71 mean ratio for board composition suggests that non-executive directors occupy a high proportion $(71 \%)$ of most of the firms' boards, which is an indication of a relatively independent board. In addition, $85.20 \%$ was recorded by firms with the highest number of nonexecutive directors' representation on their boards. By implication, most of the firms largely depended on the outside directors and are therefore relatively independent of the Chairmen their boards and Chief executive. CEO duality is rarely seen in the sampled firms, with a mere $4.9 \%$ of firms adopting this type of leadership structure and an overwhelming majority of $95.1 \%$ firms opting for independent chairman recommended by the SEC code of corporate governance (SEC code, 2011). A maximum of $162 \%$ with very few firms recording negative growth and average growth opportunities for the firms are about $7.5 \%$ were observed.

This sort of descriptive statistic may help offer some insight into the basic features of the underlying data upon which the analysis is based. However, by its nature, descriptive analysis has a major limitation; it does not lend itself to statistical tests and consequently useless in drawing general conclusions over a different period of about firms outside the sample.

Table 2 (Appendix B) presents the correlation results for the sampled firms. This analysis provides a first simple test of our proposed hypothesis as it can be seen that a number of them are consistent with the research hypotheses. For example, there is a positive correlation between firm size and board size while age has a negative correlation with board composition. It can also be seen that firm size and leverage have positive correlation with board composition while growth opportunities, profitability and CEO duality are negatively correlated with board composition as earlier hypothesized in this study.

A mean of 95.1 percent suggests that most of the firms have two different individuals occupying the positions of CEO and board chairperson. The situation indicates the presence of fewer agency problems and less conflict of interest. This may be necessary to allow for the smooth running of the business enterprises in decision making and enhanced performance.

\section{Analysis of Results}

Table 3 (Appendix C) presents the reports of the pooled regression along with the fixed and random effects estimates using the board size as the dependent variable. The results indicated a significant positive relationship between board size and firm size which is in line with hypothesis one. This implies that a strong determinant of 
board size is firm size. This result signifies that a larger board size is required by larger firms. This position is in line with the assumption of the resource dependence theory that larger boards are made up of members from different backgrounds that bring to the board varying professional expertise and skills (Pfeffer \& Salancik, 1978). Also, leverage and profitability are found to have a positive relationship with board size, though with a rather small coefficient value, in line with hypothesis two. It was concluded based on this that these variables are determinants of board size.

The implication of this result shows that the identified variables were significant in predicting firms' profitability. Though, it was observed that the coefficient of some of these variables were low but positive. The pooled regression results show a significant $p$-value which indicates a positive and significant effect. This, however, is in concordant with the study hypothesis four. Thus, to enhance growth opportunities, boards are expected to be smaller. This is in line with the findings in the studies conducted by Lipton and Lorsch (1992) and Jensen (1993). It is worth noted that, the bigger a board gets, the more difficult it becomes to the coordinator. On the other hand, the small the board, the lower the possibility of freeriding by and increase decision-making process (Sanda, Mukaila \& Garba, 2005). Hence, this study concluded that growth opportunity is another determinant of board size. The result further established a significant positive relationship between age and board size in all cases. Thus, indicating that age is a determinant of board size in the sampled firms. This is in line with the work of Boone et al (2007) that found that as firms grow board also grows in response to the increasing needs and benefits of monitoring and specialization by board members.

The CEO duality coefficient reported on the board size analysis is positive and significant in the cross-section regression but not significant in the pooled regression as opposed to hypothesis three. This result suggests that the board will be larger in the firms where the two positions of the chairman and chief executives are combined in the sampled firms. This result is an unexpected one. However, it could mean that appointment of inside directors seems to be driven by other factors other than economic such as political consideration or substantial family share ownership in the firms.

Table 4 (Appendix D) shows the pooled regression along with the fixed and random effects estimates with the board composition as the dependent variable. The relationship between firm size and board composition is positive and significant in line with hypothesis one. However, the average number of outside directors in the sampled firms is relatively small. This is just about six compared with the U.S average of eleven (Prasama, 2012). This result means that lager firms require larger board composition and so firm size is a determinant of board composition. Similarly, the result indicates that firms characterised by high leverage are associated with a higher proportion of outside directors as leverage is positively related to board composition in all cases in support of hypothesis two. Based on this, it is concluded that leverage is a strong determinant of board composition. With regards to the relationship between profitability and board composition, the study finds support for hypothesis four that firms characterized by high profitability have a smaller proportion of outside directors. This is in line with the position of Harmalin and Weishbach (1988), Kaplan and Milton (1994) and Peng (2004) which discovered that poor performance of a company comparative to that of its rival and industry competitors provoke appointment of an outside director in replacement of the insider directors. It is, 
therefore, concluded that firm profitability determines corporate board composition. The report finds support for hypothesis four that firm growth opportunities will be negatively related to board composition. This is true in all cases though the result is not significant for the pooled regression. Thus, the growth opportunity is a strong determinant of board composition in the sampled firms.

With regard to age which is used as a proxy for measuring firm complexity, the sample is made up of mature firms selected considering the mean age of forty-three (Garen, Instituto \& Antonio, 2010). The research result could not establish a positive relationship between this variable and board composition as reflected in the pooled results. This is an indication that age is not a determinant of board composition in the firms sampled. The result tends to be in support of the argument that as the end of the product life cycle is approached by older firms, they tend to reduce the number of outside directors.

Besides, the situation could further be explained by the fact that the trust and confidence of its shareholders could be won by a reputable organization as they grow older. This will, therefore, requires relatively relaxed checks and balances to ensure that the interests of the shareholders are pursued.

Finally, a positive and significant $\mathrm{CEO}$ duality coefficient was reported for the board composition in the pooled and cross-section regressions. This finding also suggests that there will be an increase in the proportion of outsiders where the two positions are combined. This implies neutralization of the power of an individual who combines the two positions since stronger CEO power is expected to be balanced by greater board independence, hence making this result logical.

\section{Discussion of findings}

The obtained variance inflation factor (VIF) is between 1 and 10, hence, it can be concluded that there is no multicollinearity issue among the variables of the study. Further, the tolerance value for the model is greater than 0.10 (see appendix) which indicates that the residuals are normally distributed and has a goodness of fit.

The first hypothesis indicated a significant positive relationship between board size and firm size. This implies that a strong determinant of board size is firm size. This result signifies that a larger board size is required by larger firms. This result is in line with the findings of Boone, Field, Karpoff and Raheja (2007) and Pfeffer and Salancik (1978) resource dependence theory which by implication allows for different sources of ideas for better performance. The findings revealed that the board size in the sampled area is small compares to what is obtainable in other countries such as U.S. and Ghana. For effective decision, board size should be increase.

The second hypothesis posits that leverage and profitability are found to have a positive relationship with board size. This is in line with the study of Prasama (2012); Coles, Daniel and Naveen (2008) and Linck, Netter and Yang (2008). However, there is positive and significant CEO duality coefficient with board composition in the pooled and crosssection regressions. This is in agreement with the findings of Kieschnick and Moussawi (2004) which implies that leverage has a positive impact on the extent of outsider representation on the board and inside directors. The fourth hypothesis revealed that to enhance growth opportunities, boards are expected to be smaller. With this, the bigger a board gets, the more difficult it becomes to coordinate. On the other hand, the small the board, the lower the possibility of free- 
riding by and increase decision-making process. This submission is in line with the study of Sanda, Mukaila \& Garba, (2005); Boone et al (2007); Guest, (2008); and Linck, Netter and Yang, (2008). Hence, this study concluded that growth opportunity is another determinant of board size.

\section{Conclusion}

and

\section{Recommendations}

Based on the above findings, it was concluded that there is a positive relationship between firm size, age, leverage, growth opportunities, profitability and board size. However, out of these variables, firm size, growth opportunities and profitability provide strong evidence as determinants of board size as indicated by the high value of their coefficients of parameter estimates and level of significance relative to other variables. Similarly, there is also strong evidence that profitability and CEOduality are determinants of board composition given the values of their coefficients and level of significance relative to other variables in the result.

In line with the above results which established a positive relationship between firm size and board size and that firm size and board composition are positively related, it is recommended that management of corporations should take advantage of this relationship especially the ones between firm size, growth opportunities and profitability to determine its board size and composition. This is in line with the resource base theory enunciated in the study by ensuring the appointment of board members based on proven demonstration of a high level of skill, expertise and merit rather than social factors, political consideration and government intervention. This will ensure that the board structure of the firms is in tandem with their characteristics.

\section{Limitations and Suggestions for Future Research}

The study analysis results are fairly consistent irrespective of whether pooled regression or the fixed effects estimates are used. However, because the study suffers some limitations, caution must be exercised with the level of confidence with which the results are validated. Firstly, the explanatory powers of the parameter estimates are too low. The implication of this is that non-economic factors greatly influence the variations in board size and composition. Secondly, the sample firms comprised only listed manufacturing firms. Though a sizeable number of manufacturing-oriented firms are included, a larger sample incorporating industries in operations similar to the manufacturing sector may result in a more significant finding. Nevertheless, the basic data was expanded to a 390 firm-year observation through the application of panel data, deemed suitable for panel data regression. Though, these shortcomings have been compensated for by the nature of the econometric techniques adopted, with numerous data sets over the cross-section, in the analysis of the data. Consequently, it is suggested, that future researches should explore the non-economic factors that are excluded from this study to measure appropriately the effects of the variables that may be considered relevant in the determination of corporate board size and composition in the Nigerian context. Also, it was observed from the study that, the board size affect profitability and profitability affect board size. This endogeneity issue is links as a result of reverse causality, further research can check the extent of this reverse causality. Despite these limitations, this study does contribute significantly to the few existing literatures on the determinants of board size and composition in Nigeria. It further fosters the understanding of corporate governance issues with particular 
reference to the determinants of board size and composition of listed manufacturing firms the Nigerian stock.

\section{References}

Adams, R., \& Mehran, H. (2003) Is corporate governance different for bank holding companies? Economic Policy Review, $\quad 9 \quad$ (1), 191. https://www.newyorkfed.org/medialibrar y/media/research/epr/03v09n1/0304adam .html (text/html)

Andres, P. \& Vallelado, E. (2008) Corporate governance in banking: The role of the board of directors, Journal of Banking and Finance, 32(12), pp 2570-2580 http://www.sciencedirect.com/science/art icle/pii/S0378-4266(08)001000-3

Bathala, C. T., \& Rao, R. P. (1995) The determinants of board composition: An agency theory perspective, Managerial and Decision Economics, 16, 59-69. doi:10.12691/ijefm-3-2-2

Baysinger, B. D., \& Butler, H. N. (1985) Corporate governance and the board of directors: Performance effects of changes in board composition. Journal of Law, Economics, \& Organization, 1, 101-124. doi: 10.12691/jfa-2-4-2.

Baysinger, B., \& Hoskisson, R. E. (1990) The composition of boards of directors and strategic control: Effects on corporate strategy, The Academy of Management Review, 15(1), 72-87. http://links.jstor.org/sici?sici=0363$7425 \% 28199001 \% 2915 \% 3 \mathrm{~A} 1 \% 3 \mathrm{C} 72 \% 3$ ATCOBOD\%3E2.0.CO\%3B2-X

Beatty, R. P., \& Zajac, E. J. (1994) managerial incentives, monitoring and risk bearing: A study of executive compensation, ownership, and board structure in initial public offerings, Administrative Science Quarterly, 39, 313-335. Doi: 1745-6622.1995.tb00291.x
Bhagat, S., \& Black, B. (2000) The uncertain relationship between board composition and firm performance, Business Lawyer, 54, 569-598. http://papers.ssrn.com/papers.taf?abstract _id $=11417$

Boone, A. L., Field, L. C., Karpoff, J. M., \& Raheja, C. G. (2007) The determinants of corporate board size and Composition: An empirical analysis. Journal of Financial Economics, 85(1), 66-101. http://www.sciencedirect.com/science/art icle/pii/S0304-405X(07)00031-1

Booth, J. R.; Cornett, M. M., \& Tehranian, H. (2002) Board of directors' ownership and regulation. Journal of Banking and Finance, 26(1), 1973-1995. HAL Id: halshs-00009115https://halshs.archivesouvertes.fr/halshs-00009115

Booth, J. R. \& Deli, D. N. (1996) Factors affecting the number of outside directorship held by CEOs, Journal of financial economics, 40, $81-104$. http://www.sciencedirect.com/science/art icle/pii/0304-405X (95)00838-6

Booth, J. R., \& Deli, D. (1999). On executives of financial institutions as outside directors. Journal of Corporate Finance, 5, 227-250. http://www.sciencedirect.com/science/art icle/pii/S0929-1199(99)00004-8

Boyd, B. K. (1995). CEO duality and firm performance: A contingency model. Strategic Management Journal, 16(4), 301-312.

https://doi.org/10.1002/smj.4250160404

Chambers N., Harvey G., Mannion R., Bond J., Marshall J. (2013) Towards a framework for enhancing the performance of NHS boards: A synthesis of the evidence about board governance, board effectiveness and board development, Health Services and Delivery Research, No. 1 (6):1-137. doi: 10.3310/hsdr01060 
Mustapha Y. I., Nafiu A. I., Abdul F. A. and Omolekan, O. J., KJM, 2020, 09 (01)

Cadbury report. (1992). Report of committee on the financial aspects of corporate governance. doi: 10.4236/me.2012.37109

Campion, A., \& Frankiewicz, C. (1999). guidelines for the effective governance of microfinance institutions. Washington DC: The Microfinance Network.

Chen, H. L. (2011). Does board independence influence the top management team? Evidence from strategic decisions toward internationalization. Corporate Governance: An International Review, 17. https://doi.org/10.1111/j.1467-

8683.2011.00850.x

Coles, L.; Daniel, D. \& Naveen, L. (2008). Boards: does one size fit all. Journal of Financial Economics, 87(2), 329-356. https://doi.org/10.1016/j.jfineco.2006.08. 008

Conger, J. Finegold, D. \& Lawler, E. (1999). Board composition: Member selection and appointment. In $\mathrm{M}$. Newwork. (Ed.), Guidelines for the effective governance of microfinance organizations, $9, \quad 16$. https://doi.org/10.1177/09726527135129 16

Daily, C., \& Dalton, D. (1993). Board of directors leadership and structure: Control and performance implications. Entrepreneurship Theory and Practice, 17(3), 17. https://doi.org/10.1177/01492063020280 0307

Dalton, D. R.; Daily, C. M.; Johnson, J. L., \& Ellstrand, A. E. (1999). Number of directors and financial performance: A meta-analysis. Academy of Management Journal, 42(6), 674-686. https://doi.org/10.2307/256988

Denis, D., \& Sarin, A. (1999). Ownership and board structure in publicly traded corporations, Journal of Financial Economics, 52, 187-223. doi: 10.12691/ijefm-3-2-2.

Fama, E. (1980). Agency problems and the theory of the firms. Journal of Political Economy,88, 288-307. https://doi.org/10.1086/260866

Fama, E., \& Jensen, M. C. (1983): Separation of ownership and control. Journal of Law and Economics, 26, 301325. http://dx.doi.org/10.1086/467037.

Fields, M. A., \& Keys, P. Y. (2003). The emergence of corporate governance from Wall St. to Main St. outside directors, board diversity, earnings management and managerial incentives to bear risk. Financial Review, 38(1), 1-24. doi:10.1111/1540-6288.00032

Gregory, B. T.; Rutherford, M. W.; Oswald, S. \& Gardiner, L. (2005). An empirical investigation of the growth cycle theory of small firm financing. Journal of Small Business Management,43(4), 382-392. https://doi.org/10.1111/j.1540-

627X.2005.00143.X

Guest, P. M. (2008). The determinants of board size and composition: Evidence from the UK. Journal of Corporate Finance, 14, 51-72. http://dx.doi.org/10.1016/j.jcorpfin.2008. 01.002

Hermalin, B. E., \& Weisbach, M. S. (1988): The Determinants of board composition. The Rand Journal of Financial Economics, 19(4), 589-606. doi:10.1016/0304-405X(76)90026-X

Hermalin, B. E., \& Weisbach, M. S. (1998). Endogenously chosen boards of directors and their monitoring of the CEO, American Economic Review, 88, 96-118. http://links.jstor.org/sici?sici=0002$8282 \% 2819980$ 3B2$\% 23 \&$ origin $=$ repec 
Hillman, A., \& Dalziel, T. (2003). Boards of directors and firm performance: integrating agency and resource dependence perspectives. The Academy of Management Review, 28(3), 383-396. https://doi.org/10.5465/amr.2003.101967 29

Hsiao, C. (2003): Analysis of panel data. Cambridge: Cambridge University Press.

Ifeanyi, D. N., Olagunju, A., \& Adeyanju, O. D. (2011). Corporate governance and bank failure in Nigeria: Issues, challenges and opportunities. Journal of Finance and Accounting, 2(2), 5.

Iwasaki, I. (2008). The Determinants of board composition in a transforming economy: Evidence from Russia. Journal of Corporate Finance, 14(5), 532-549.

Jackling, B., \& Johl, S. (2009). Board structure and firm performance: Evidence from Indians top companies. Corporate Governance: An International Review, 17(4), 492-509.

Jensen, M. C., \& Meckling, W. H. (1976). Agency cost and the theory of the firm, Journal of Financial Economics, 3, 305360.

Jensen, M., \& Meckling, W. (1976). Theory of the firm: Managerial behavior, agency costs and ownership structure. Journal of Financial Economics, 3, 55. doi: 10.1002/9780470752135.ch17

Johnson, J., Daily, C., \& Ellstrand, A. (1996). Boards of directors: A review and research agenda. Journal of Management, 22(3), 409-438. https://doi.org/10.1177/01492063960220 0303

Kaplan, S. N., \& Minton, B. A. (1994). Appointments of outsiders to Japanese boards: Determinants and implications for managers. Journal of Financial Economics, 36(2), 225-258.
Kieschnick, R., \& Moussawi, R. (2004). The board of directors: A bargaining perspective? University of Texas at Dallas, Working Paper, 5, 67.

Kim, K. A., Kitsabunnarat, P., \& Nofsinger, J. R. (2007). Large shareholders, board independence, and minority shareholders rights: Evidence from Europe. Journal of Corporate Finance, 13(5), 859- 880. Handle: RePEc:eee:corfin:v:13:y:2007:i:5:p:859880

Klevmarken, N. A. (1989). Panel studies: What can we learn from them? introduction. European Economic Review, 33, 523-529.

Klein, A. (1998). Affiliated directors: Puppets of management or effective directors? New York University, Center for Law and Business, Working Paper, 98010. http://ssrn.com/abstract=10569

Kyereboah, C. A. (2007). Corporate governance and firm performance: $A$ dynamic panel analysis. Paper Presented at the International Conference on Corporate Governance in Emerging Markets. Sabanci University, Instanbul, Turkey.

Kyereboah-Coleman, A. and Biekpe, N. (2007), On the determinants of board size and its composition: additional evidence from Ghana, Journal of Accounting \& Organizational Change, 3(1), 68-77. https://doi.org/10.1177/0258042X156015 33

Lehn, K., Patro, S. \& Zhao, M. (2009). Determinants of the size and structure of corporate boards. Journal of Financial Management,31, 464-481.

Liao, L., Luo, L. \& Tang, Q. (2015) Gender diversity, board independence, environmental committee and greenhouse gas disclosure, The British Accounting 
Review, 47(4), pp 409-424. https://doi.org/10.1016/j.bar.2014.01.002

Linck, J. S.; Netter, J. M., \& Yang, T. (2008). The determinants of board structure. Journal of Financial Economics, $\quad$ 87(2), 308-328. https://doi.org/10.1016/j.

jfineco.2007.03.004

Lipczinsky, J., \& Wilson, J. (2001). Industrial organization: An analysis of competitive markets. London: Prentice Hall.

Lipton, M., \& Lorsch, J. W. (1992). A Modest proposal for improved corporate governance. Business Lawyer,48, 59-77. doi: 10.12691/jfa-5-3-4.

Mallin, C. Farag, H. \& Ow-Yong, K. (2014) Corporate social responsibility and financial performance in Islamic banks, Journal of Economic Behavior and Organization, Vol.103. doi: 10.1016/j.jebo.2014.03.001

Markarian, G., \& Parbonetti, A. (2007). Firm complexity and board of director composition. Corporate Governance: An International Review, 15(6), 1224-1243. https://doi.org/10.1111/j.1467-

8683.2007.00643.x

Muth, M. M., \& Donaldson, L. (1998). Stewardship theory and board structure: A contingency approach to corporate governance. An International Review, 6(1), 5-28.

Nigeria Security and Exchange Commission (SEC). (2003 \& 2011): Code of Corporate Governance.

Nigerian Stock Exchange. (2011/2012). Fact book. Lagos: The Nigeria Stock Exchange.

Pearce, J., \& Zahra, S. (1992). Board composition from a strategic contingency perspective. Journal of Management Studies, 29(4), 411-438.
Peng, M. (2004). Outside directors and firm performance during institutional transitions. Strategic Management Journal, 25(5), 453-471. https://doi.org/10.1002/smj.390

Pfeffer, J., \& Salanick, G. R. (1978). The external control of organizations: A resource dependence perspective. New York: Harper \& Row Publishers.

Pfeffer, J. (1972). Size and composition of corporate boards of directors: The organization and its environments. Administrative Science Quarterly, 17, 218-229.

Pincus, K., Rusbarsky, M., \& Wong, J. (1989). Voluntary formation of corporate audit committee among NASDAQ firms, Journal of Accounting and Public Policy, 8, 239-265.

Raheja, C. (2005). Determinants of board size and composition: A theory of corporate boards. Journal of Financial and Quantitative Analysis, 40(02), 283. https://www.cambridge.org/core/product/ identifier/ ... type/journal_article

Sanda, A. U., Mukaila, A. S., \& Garba, T. (2003). Corporate governance mechanisms and firm financial performance in Nigeria, Final report to the biannual research workshop of the AERC, Nairobi, Kenya, AERC Research Paper, 149, 24-29.

Stavarek, D. (2005). Efficiency of banks in regions at different stages of European integration process.Czech Journal of Economics and Finance, 55(3-4), 141161.

Steier, M. (1998). Confounding market and hierarchy in venture capital governance: The Canadian immigrant investor program. Journal of Management Studies, 35(4), 511. https://doi.org/10.1111/1467-6486.00107 
Mustapha Y. I., Nafiu A. I., Abdul F. A. and Omolekan, O. J., KJM, 2020, 09 (01)

Strom, O., D'Espallier, B., \& Mersland, R. (2010). Gender, performance and governance in microfinance, institutions $3^{\text {rd }}$ International Workshop on Microfinance Management and Governance, University of Groningen, 36.

Whidbee, D. A. (1997). Board composition and control of shareholder voting rights in the banking industry. Financial Management, 26, 27-41. https://doi.org/10.1023/A:

Wier, C., \& Laing, D. (2001). Governance structure, director independence and corporate performance in UK. European Business Review, 13(2), 86-95.

Wooldridge, J. (2006). Introductory econometrics: A modern approach ( $3^{\text {rd }}$ ed.). Ohio: Thomson South Western.

Yermack, D. (1996). Higher market valuation of companies with a small board of directors. Journal of Financial Economics, 40, 185-211. http://dx.doi.org/10.1016/0304-405X(95)

Zahra, S. A. \& Pearce, J. A. (1989). boards of directors and corporate financial performance. Journal of Management, $15(2)$, 291-334. https://doi.org/10.1177/01492063890150 0208 
Mustapha Y. I., Nafiu A. I., Abdul F. A. and Omolekan, O. J., KJM, 2020, 09 (01)

\section{Appendices}

\section{Appendix A}

Table 1: Descriptive Statistics

\begin{tabular}{lrrrrrr}
\hline Variables & Observations & Mean & Median & Maximum & Minimum & Std. Dev. \\
bds & 390 & 7.001 & 8.500 & 14.000 & 3.000 & 2.321 \\
bdc & 390 & 0.712 & 0.690 & 0.852 & 0.500 & 0.081 \\
age & 390 & 43.012 & 39.000 & 72.000 & 8.000 & 14.231 \\
ceo & 390 & .951 & 1.000 & 1.000 & 0.000 & 0.211 \\
fz & 390 & 6.319 & 6.201 & 8.940 & 4.444 & 0.701 \\
gro & 390 & 0.075 & 0.076 & 1.623 & -2.001 & 0.295 \\
lev & 390 & 0.501 & 0.399 & 2.119 & -0.089 & 0.481 \\
pro & 390 & 0.210 & 0.079 & 1.534 & -0.499 & 0.301 \\
\hline
\end{tabular}

Source: Authors' Computation from E-view panel data output

Note: Corporate governance variables were analyse using descriptive statistics such as measures of central tendency and measures of dispersion from E-view software panel data

\section{Appendix B}

Table 2: Correlation Statistics

\begin{tabular}{lrrrrrrrr}
\hline $\begin{array}{l}\text { Var. } \\
\text { bds }\end{array}$ & \multicolumn{1}{l}{ bds } & \multicolumn{1}{l}{ Bdc } & \multicolumn{1}{l}{ fz } & age & lev & gro & pro & ceo \\
bdc & 0.210 & 1.000 & & & & & & \\
fz & 0.290 & 0.499 & 1.000 & & & & & \\
age & -0.181 & 0.102 & -0.059 & 1.000 & & & & \\
lev & 0.204 & 0.011 & -1.121 & 0.044 & 1.000 & & & \\
gro & -0.091 & -0.301 & 0.042 & -0.040 & -0.038 & 1.000 & & \\
pro & -0.211 & 0.318 & 0.298 & -.243 & -0.119 & 0.021 & 1.000 & \\
ceo & -0.062 & 0.048 & 0.321 & 0.218 & 0.212 & 0.049 & 0.111 & 1.000 \\
\hline
\end{tabular}

Source: Authors' Computation from E-view panel data output.

Note: Corporate governance variables were analyse using correlation matrix on E-view software panel data

\section{Appendix C}

Table 3: Regression Results of Determinants of Board Size (bds)

\begin{tabular}{|l|r|r|r|}
\hline Variable & Pooled OLS & Fixed Effect & \multicolumn{1}{|c|}{ Random Effect } \\
\hline Constant & $0.7520^{* *}$ & $10.0010^{* *}$ & $9.2154^{* * *}$ \\
& $(0.0421)$ & $(0.0434)$ & $(0.0445)$ \\
\hline Pro & $1.5123^{* *}$ & 1.2143 & 1.4251 \\
& $(0.0411)$ & $(0.0351)$ & $(0.0445)$ \\
\hline Fz & $1.4891^{* *}$ & $1.2461^{* *}$ & $1.1470^{* *}$ \\
& $(0.0212)$ & $(0.0145)$ & $(0.0258)$ \\
\hline Lev & $1.2578^{* *}$ & $0.3235^{*}$ & 0.2435 \\
& $(0.0251)$ & $(0.0142)$ & $(0.0251)$ \\
\hline Age & $0.7017^{*}$ & $0.6151^{* *}$ & $0.1169^{* *}$ \\
& $(0.0010)$ & $(0.0406)$ & $(0.0260)$ \\
\hline
\end{tabular}


Mustapha Y. I., Nafiu A. I., Abdul F. A. and Omolekan, O. J., KJM, 2020, 09 (01)

\begin{tabular}{|l|r|r|r|}
\hline Gro & $1.8451^{* *}$ & $1.0017^{*}$ & $1.2457^{* *}$ \\
& $(0.0359)$ & $(0.0112)$ & $(0.0264)$ \\
\hline Ceo & $0.4122^{*}$ & $0.5647^{* *}$ & $0.6421^{* *}$ \\
& $(0.0125)$ & $(0.0340)$ & $(0.0312)$ \\
\hline $\mathrm{R}^{2}$ & 0.5267 & 0.6241 & 0.4739 \\
\hline F & $121.02^{* *}$ & $134.82^{*}$ & \\
\hline Chi $^{2}$ & & & $101.12^{*}$ \\
\hline Hausman Test & & & $314.11^{*}$ \\
\hline No. obs & 390 & 390 & 390 \\
\hline
\end{tabular}

Significant at $(1 \%)^{*},(5 \%)^{* *},(10 \%)^{* * *}$, Standard Error in parenthesis.

Source: Authors' Computation from E View Panel Data Regression Output.

Note: Corporate governance variables were regress with pooled ordinary least square of fixed and random effect (Hausman Test) for the determinants of board size on E-view software panel data

\section{Appendix D}

Table 4: Regression Results of Determinants of Board Composition (bdc)

\begin{tabular}{|l|r|r|r|}
\hline Variable & Pooled OLS & Fixed Effect & Random Effect \\
\hline Constant & $0.6548^{* *}$ & $0.5781^{*}$ & $0.7541^{*}$ \\
& $(0.0214)$ & $(0.01954)$ & $(0.0012)$ \\
\hline Pro & $-0.0537^{* *}$ & -0.0468 & $-0.0741^{* * *}$ \\
& $(0.0312)$ & $(0.0412)$ & $(0.0541)$ \\
\hline Fz & $0.4872^{*}$ & 0.3697 & $0.5412^{* *}$ \\
& $(0.0021)$ & $(0.0312)$ & $(0.0112)$ \\
\hline Lev & 0.6598 & $0.4532^{* * *}$ & 0.0150 \\
& $(0.0041)$ & $(0.1019)$ & $(0.0173)$ \\
\hline Age & $-0.0721^{* *}$ & $0.0421^{*}$ & -0.0647 \\
& $(1.0657)$ & $(1.0043)$ & $(1.0091)$ \\
\hline Gro & -0.0685 & $-0.0510^{*}$ & $-0.0498^{*}$ \\
& $(0.0022)$ & $(0.0050)$ & $(0.0032)$ \\
\hline Ceo & $0.7326^{* *}$ & $0.4875^{*}$ & -0.0210 \\
& $(0.0322)$ & $(0.0003)$ & $(0.0412)$ \\
\hline $\mathrm{R}^{2}$ & 0.4571 & 0.4023 & 0.4964 \\
\hline F & $46.598^{* *}$ & $45.214^{* *}$ & $214.11^{* *}$ \\
\hline Chi ${ }^{2}$ & & & $104.15^{*}$ \\
\hline Hausman Test & & & 390 \\
\hline No. Obs & 390 & 390 & \\
\hline
\end{tabular}

Significant at $(1 \%,)^{*}(5 \%)^{* *},(10 \%)^{* * *}$, Standard Error in parenthesis.

Source: Authors' Computation from E View Panel Data Regression Output.

Note: Corporate governance variables were regress with pooled ordinary least square of fixed and random effect (Hausman Test) for the determinants of board composition on E-view software panel data 